\title{
Service Quality, Customer Satisfaction and Loyalty in an Internet Service Providers
}

\author{
Jamal M. M. Joudeh ${ }^{1} \&$ Ala' O. Dandis ${ }^{1}$ \\ ${ }^{1}$ Marketing Department, Business Faculty, Applied Science Private University, Amman, Jordan \\ Correspondence: Jamal M. M. Joudeh, Business Faculty, Applied Science Private University, Amman, Jordan. \\ E-mail: jamaljoudeh@asu.edu.jo
}

Received: March 21, 2018

doi:10.5539/ijbm.v13n8p108
Accepted: June 20, 2018

Online Published: June 30, 2018

URL: https://doi.org/10.5539/ijbm.v13n8p108

\begin{abstract}
The current study aimed at examining the influence of service quality (internet service quality) on customer loyalty through the mediating effect of customer satisfaction. Through employing the questionnaire on a convenient sample of (860) consumer from different malls and commercial complexes in Amman - Jordan; the results indicated that internet service quality has a positive influence on customer satisfaction which in its turn can influence the level of customer loyalty. The study also reached to the results that good and well-built service quality may lead to customer satisfaction which in its turn can lead to a better level of customer loyalty. Consumer loyalty includes highlights or attributes that can fulfill the desires or needs of a client, it is a post utilization encounter which contrasts apparent quality and expected quality, in this way a similar conduct between inputs previously and after utilization. The study recommended to enhance the level of service quality awareness is the best approach to customer satisfaction. Aware employees tend to pay more attention to the idea of service quality which can lead to a better customer loyalty.
\end{abstract}

Keywords: customer loyalty, customer satisfaction, service quality, internet

\section{Introduction}

Service quality is becoming one of the most important aspects in the field of services. Customers are now more aware of the level of the service they get which has led the organization to give more attention to the level of the service they provide to their customers in order to be able to get more satisfaction which can lead to better loyalty from customers. Due to the exceptional rivalry and the antagonistic vibe of natural components, service quality has turned into a foundation advertising procedure for organizations. This features how vital enhancing service quality is to associations for their survival and development since it could enable them to handle these difficulties they look in the aggressive markets. This implies benefit based organizations are constrained to give astounding service to their clients with a specific end goal to have a reasonable upper hand. There is in any case, a requirement for these associations to comprehend what service quality is with a specific end goal to achieve their destinations.

\subsection{Statement of the Problem}

Service quality and consumer loyalty are essential ideas that organizations must comprehend so as to stay focused in business and thus develop it. It is vital for organizations to know how to gauge these builds from the buyers' point of view with a specific end goal to better comprehend their requirements and consequently fulfill them. Service quality is viewed as imperative since it prompts higher consumer loyalty, benefit, less cost, client devotion and maintenance. According to Chingang and Lukong (2010) service quality was defined as "the overall assessment of a service by the customers". Based on that, the level of the service is determined by customers is seen very important by the organization to determine the ability of the organization to deliver such service and to satisfy customers leading to their satisfaction. From that point, the current research study aims at understanding the mediating role of satisfaction within the internet service quality field in delivering customer to the status of loyalty to the organization.

\subsection{Objectives and Hypotheses}

Through the hypotheses the current study will be able to reach the following set of objectives including:

- Identify the level of internet service quality in Jordan 
- Examine the degree of awareness about customer satisfaction and service quality among organizations under examination

- $\quad$ Highlight the best approaches to increase customer satisfaction

- Connect between customer satisfaction and their loyalty towards the organization through the quality of the service

As for the hypotheses, the current study will try to achieve the following set of hypotheses:

H (1): Internet Service Quality has a Significantly Positive Impact on Customer Satisfaction.

H (2): Internet Service Quality Dimensions have a Significantly Positive Impact on Customer Satisfaction Separately.

H (3): Internet Service Quality has a Significantly Positive Impact on Customer Loyalty.

H (4): Service Quality Dimensions have a Significantly Positive Impact on Customer Loyalty separately.

H (5): Service Quality and Customer Satisfaction have a Significantly Positive Impact on Customer Loyalty.

H (6): Internet Service Quality Dimensions and Customer Satisfaction have a Significantly Positive Impact on Customer Loyalty Separately.

\section{Service Quality Dimensions}

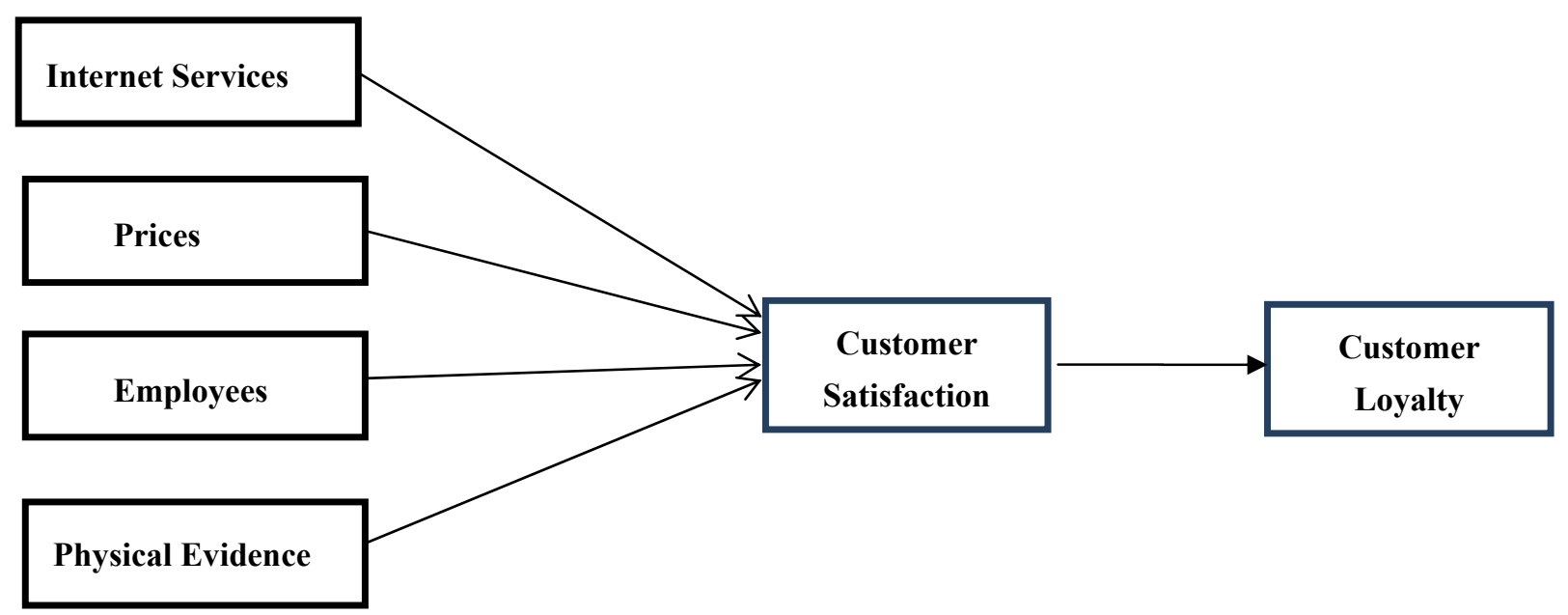

Figure 1. Conceptual framework

\section{Literature Review}

Customer satisfaction, customer loyalty and service quality have increasingly become importance concepts in the today's competitive market. Companies that seek to grow and remain competitive tend to give attention to these three variables. It is suggested that satisfied customers are more likely to remain loyal to a brand, make repeat purchases, and offer a positive word of mouth and consequently market the company. It is also suggested that customers who feel the good experience of quality service often tend to share their good experiences with others leading to an expanded customer base and that such customers tend to become loyal customers (Spreng, \&Mackoy, 1996). Conversely, dissatisfied customers tend to share the bad experiences with the poor quality of service with others and this leads to reduced purchases and customer base (Smith, \& Bolton, 2002). On this basis, studies have suggested a relationship between service quality, customer satisfaction and customer loyalty. This literature review explores the studies that suggested the relationship between customer loyalty, customer satisfaction and service quality. First, it explores the concept of service quality as conceptualized and documented in the academic literature. Secondly, internet service quality and its four dimensions, namely core, price, environment and employee are explored. Thirdly, the concepts of customer loyalty and customer satisfaction as documented in the marketing literature are explored. Lastly, the relationship between customer loyalty, customer loyalty and internet service quality as documented in the literature are explored.

\subsection{Service Quality}

Service providers often seek to understand what external or internal customer care about or are concerned about. 
Product quality, or service quality count and they are a good guess. This is also a concern for most customers. As defined by Parasuraman et al. (1988) service quality is the evaluation of a service by customers achieved by comparing its actual performance and the genera expectations of its performance. It can also refers to the difference in expectations by customers regarding its performance and its actual performance (Parasuraman et al., 1988; 1985). Parasuraman et al. (1988) identified five dimensions of service quality identified as SERVQUAL dimensions: tangibles, reliability, assurance, empathy and responsiveness. Tangible concerns the appearance of equipment, physical facilities, communication materials and personnel. This dimension translates to the appearance and interior of the organization. It signals quality and conveys the image of a firm (Zeithaml et al., 2006). Reliability concerns the ability of service to dependably and accurately perform the promised service or delivering on its promises (Zeithaml et al. 2006). According to Zeithaml et al. (2006) noted that reliability as a dimension of service quality is critical as customers often want to companies that implicitly communicate and keep to their promises. Responsiveness refers to the willingness to offer prompt service and help customers (Zeithaml et al., 2006). It is concerned with customers' requests, complaints and questions attentively and promptly. A responsive firm often communicates with them and how long it takes to deal with their problems or answer their questions (Zeithaml et al., 2006). Assurance refers to the employees' courtesy and knowledge and their ability to convey confidence and trust to customers. Lastly, empathy refers to the caring and individualized attention provided by affirms to its customers. Empathy can be offered in several ways: knowing customers' name, their needs and preferences (Zeithaml et al., 2006; Andaleeb \& Conway, 2006; Harr, \& Lily, 2008).

\subsection{Customer Satisfaction}

Customer satisfaction has played a big role in the market share as well as in the company investment. Researches in the field have proposed several definitions of customer satisfaction. Many definitions focus on the disconfirmation of all expectations. Some theories explain how customer satisfaction relates to customer needs, where a customer will be satisfied once he or she feels satisfied with the product offered to them. Many times the customers have expectations towards a given product. After buying a product, a customer will expect the new product to meet his expectation. In situations where the expectations towards the product are not met, the customer will be dissatisfied.

Gilbert \&Veloutsou (2006) defined the term expectations as the preconceived perceptions or beliefs concerning delivery of service as a reference or standard point where the performance of a product may be judged. The process of taking measurements for customer satisfaction is complex. Customer satisfaction is personal in nature and differ from one customer to another making it hard to establish a standardized measurement kit for the phenomenon. Oliver (1997) redefined customer satisfaction by considering the response towards fulfillment. He noted that customer satisfaction refers to judging the features of the product or service and ensuring that the service or the product offers pleasurable consumption levels that are linked to fulfillment. In this regard, measurements of customer satisfaction consider satisfaction of needs as well as expectations. The term satisfaction comes from the word comfort, which relates to the satisfaction level with no excitement. Customer satisfaction relates to contentment, which involves passive response where customers would be less involved emotionally. Even though the definition of satisfaction touches on contentment, the presentation of a pleasant product say food, may elicit high to moderate arousal effect that may cause happiness and Joy.

Satisfaction has also been linked to the feeling of delight. Delight, in this case, refers to an individual developing a surprise in a positive way. If a customer was contented with a given product or service and the service goes through some challenges and creates a discomfort, the customer will be dissatisfied. If for some reasons the service is recovered the customer will experience relief. To put it differently, dissatisfaction model has no place for the complexities of customer satisfaction. In fact, a customer who buys a cell phone is likely to be influenced by myriad of factors that influence the product such as users' experience, the treatment given to him by the sales person, and after sale service. While a customer may be satisfied by a single aspect of the product, he or she is likely to be dissatisfied with other components of the product causing conflicting feelings on the overall product. In addition several components in a product tend to influence customer satisfaction in a different way. For instance, a customer may be satisfied with on aspect of the product in the short run but not in the long run. Also, the same customer is likely to be dissatisfied with another component of the same product. In some situations, negative evaluations on a product will influence the satisfaction for the customer (Vargo, Nagao, He, \& Morgan, 2007).

A study by Cadotte and Turgeon (1988) reported that satisfaction in influenced by satisfiers, neutrals, and dissatisfies. Accordingly, the satisfiers influence the customer's intrinsic needs, while dissatisfies influence the extrinsic needs of customers. As such, customers have basic needs put in a rank of satisfaction. Once the basic needs are satisfied, the customer will require other needs to be satisfied. Customer satisfaction will be realized 
once the intrinsic needs are met.

Another customer satisfaction model considers it as a complete assessment of accumulated consumption and purchase experience that reflects a comparison between perceived rewards and the sacrifice experienced. In this context, sacrifice include intangible costs such as energy and time spend to make arrangements and reservations and the monetary costs involved in the purchase of a service (Iglesias, \&Guillen, 2004).

\subsection{Customer Loyalty}

In the today's highly discommoded competitive business environment, customer loyalty is touted at the best approach to differentiating a business from the competition. This differentiation serves to driven loyalty in customers by engaging them intellectually, emotionally and spiritually.

As used in this context, customer loyalty may refer to the conscious evaluation of the quality or price ratio, the price difference by consumers. Elsewhere, customer loyalty has been defined as the willingness of customers to pay a high or premium price for a service (Supphellen \&Nysveen, 2001; Zaithaml, Berry \&Parasuraman, 1996). According to Raju, Srinivasan, and Lal (1990) customer loyalty encompasses loyalty behavior or customer retention, which makes customers to make avoid choosing competitor brands and instead make repeat purchases of a brand they are accustomed with. Raju, Srinivasan, and Lal (1990) added that customer loyalty is the behavioral as well as attitudinal tendency by consumers to choose one brand against others. This may be due to its convenience, performance, satisfaction with the service or product, or simply comfort and familiarity with the brand. Supporting this view, Supphellen and Nysveen (2001) opined that customer loyalty often encourage customers feel positive and enjoy the shopping experience, spend a larger share of wallet, shop more consistently, and helps attracts customers to popular and familiar brands.

According to Taylor (1997) prompting customer loyalty involves a company building an emotional bond with its customers. Taylor (1997) further noted that building loyalty in customer involves blending customer experience management with the emotional, physical and value elements of shopping experience into a cohesive experience. It has been suggested in the literature that it is less expensive to retain customers than acquiring new ones and that it is considered the most cost-effective strategy to dive customer retention, customer loyalty and customer satisfaction (Teeter, \&Schointuch, 2000). Loyal customers are known to ensure sales and are more likely to buy high-margin supplemented services and products. These customers are also known to help minimize costs associated with marketing and consumer education, especially when these customers become the organization's Net Promoters (Taylor, \& Baker, 1994). Different degrees and types of customer loyalty have been identified in the literature: attitudinal, behavioral, polygamous and monogamous (Turow, Feldman, \& Meltzer, 2005).

\subsection{Connect between Customer Satisfaction and Customer Loyalty}

A number of studies have suggested a link between customer satisfaction, service quality and customer loyalty. In an attempt to integrate customer satisfaction models with perceived quality models, Gotlieb et al. (1994) examined the effect of customer satisfaction and perceived quality on customers' behavioral intentions to purchase. Specifically, Gotlieb et al. (1994) sought to determine the relationship among perceived quality, disconfirmation of expectations, behavioral intentions, perceived situational control and satisfaction. It was revealed that the relationship between two dimensions of disconfirmation of expectations (i.e., contextual and focal dimensions) and behavioral intentions is mediated by the perceived quality and that satisfaction in the service influences behavioral intentions. It was also revealed that satisfaction in the service is influenced by the perceived quality.

In another study, Taylor and Baker (1994) empirically examined the relationship between customer satisfaction and service quality and the influence of these two variables on customers' purchase intentions. Accordingly, it was hypothesized that customer satisfaction and service quality influences the consumers' intention to purchase a service. Results confirmed the relationship between service quality customer satisfaction and consumers' intention to purchase a service.

Bei and Chiao (2001) used a sample of 495 customers of three Taiwanese automobile companies (Mitsubishi, Nissan and Toyota) to investigate the effect of perceived fairness price and perceived product quality on customer loyalty in the. The study further investigated the effect of perceived fairness, perceived service quality, and perceived product quality on customer loyalty mediated by customer satisfaction. Results indicated that customer satisfaction mediates the relationship between perceived service quality and customer loyalty.

Using a sample of five-star hotels within the Jordan context, Al-Rousan and Mohamed (2010) examined the relationship between customer loyalty and service quality dimensions namely reliability, assurance, tangibility, assurance and empathy. Data was collected from 322 participants using self-administered questionnaire. The 
study confirmed the relationship between responsiveness, tangibility, assurance and reliability and customer loyalty.

In a study involving 412 participants from the hotel industry in India, Gupta and Srivastava (2011) examined the relationship between service quality, customer loyalty and customer satisfaction. Data was collected using self-administered questionnaires and analysed using SEM technique. The study finding confirmed positive and significant relationship between service quality, customer loyalty and customer satisfaction.

Hag (2012) used a sample of 226 participants in Pakistan Auto-Mobile industry and collected data using questionnaires to investigate the relationship between customer satisfaction and customer loyalty. Results confirmed that customer loyalty and customer satisfaction are directly and strongly related. Bei and Chiao (2001) also examined the relationship between customer loyalty and perceived product quality and the customer satisfaction as mediating the relationship between perceived service quality, product quality and customer loyalty within the Taiwan automobile industry. Results confirmed that customer satisfaction mediates the relationship between customer loyalty and perceived service quality.

\section{Methodology}

The current research study was based on the quantitative approach which employed the questionnaire as a tool of the study. It is meant of employing the quantitative approach is to be able to connect between the hypotheses of the research with the perspective of the sample of the study referring to them as part of the environment under examination. As for the population and sample of the study; the researcher has considered all consumers in Amman to form the population of the study. The sample consisted of (1000) consumers from different stores and shops and commercial complexes in Amman. Through the application process; (860) individuals answered the questionnaire forming $86 \%$ of the overall sample chosen which is a percentage that is statistically acceptable. The questionnaire which was answered by the sample of the study consisted to two main parts; the first took into perspective the demographic variables of the sample (Gender, Age, Occupation, Education, Job and Exp. Amount), while the second part took into perspective questions related to the variables of the study (Internet Service, Price, employee, Physical Evidence, Customer Satisfaction, and Customer Loyalty) as shown in figure 1. The statistical processes which were used to analyze the data of the research were the regression analysis, reliability test and descriptive statistics.

\section{Results}

The current section presented the analysis of the questionnaire paragraphs and the data gathered from the sample of the study.

Table 1. Demographic characteristics of respondents

\begin{tabular}{|c|c|c|c|c|c|}
\hline Sex & Frequency & Percent & & & \\
\hline M & 506 & 58.8 & & & \\
\hline $\mathrm{F}$ & 354 & 41.2 & & & \\
\hline Total & 860 & 100.0 & & & \\
\hline Age & Frequency & Percent & Education & Frequency & Percent \\
\hline$<20$ years & 159 & 18.5 & High school & 227 & 26.4 \\
\hline $20-30$ & 363 & 42.2 & Diploma & 151 & 17.6 \\
\hline $31-40$ & 151 & 17.6 & Bachelor & 428 & 49.8 \\
\hline $41-50$ & 132 & 15.3 & Post graduates & 54 & 6.3 \\
\hline$>51$ years & 55 & 6.4 & Total & 860 & 100.0 \\
\hline Total & 860 & 100.0 & & & \\
\hline Job & Frequency & Percent & Exp. Amount & Frequency & Percent \\
\hline Student & 257 & 29.9 & $<10 \mathrm{JD}$ & 486 & 56.5 \\
\hline Civil Servant & 110 & 12.8 & 10- 20 & 251 & 29.2 \\
\hline Private & 272 & 31.6 & $21-30$ & 82 & 9.5 \\
\hline Own job & 121 & 14.1 & $31-40$ & 26 & 3.0 \\
\hline Others & 100 & 11.6 & $>41 \mathrm{JD}$ & 15 & 1.7 \\
\hline Total & 860 & 100.0 & Total & 860 & 100.0 \\
\hline
\end{tabular}

Table 1 shows the results of the gathered data in reference to the sample of the study. It appeared that most of the sample was males with a frequency of 506 individuals forming $58.8 \%$ of the total sample. This can be attributed 
to the nature of the sample which appeared to be formed mostly of males. On the other hand, $42.2 \%$ of the total sample appeared to be within the age range of 20-30 years which can be attributed to the fact that mostly the young age attended the markets. Also, $49.8 \%$ of the sample had a bachelor degree which formed almost half of the sample. In addition to that, $31.6 \%$ of the sample was working within the private sector which can explain the results regarding the results of the in reference to the expected amount which appeared to be $56.5 \%$ less than 10 JD.

Table 2. Mean S.D, factor loading and cronbach alpha

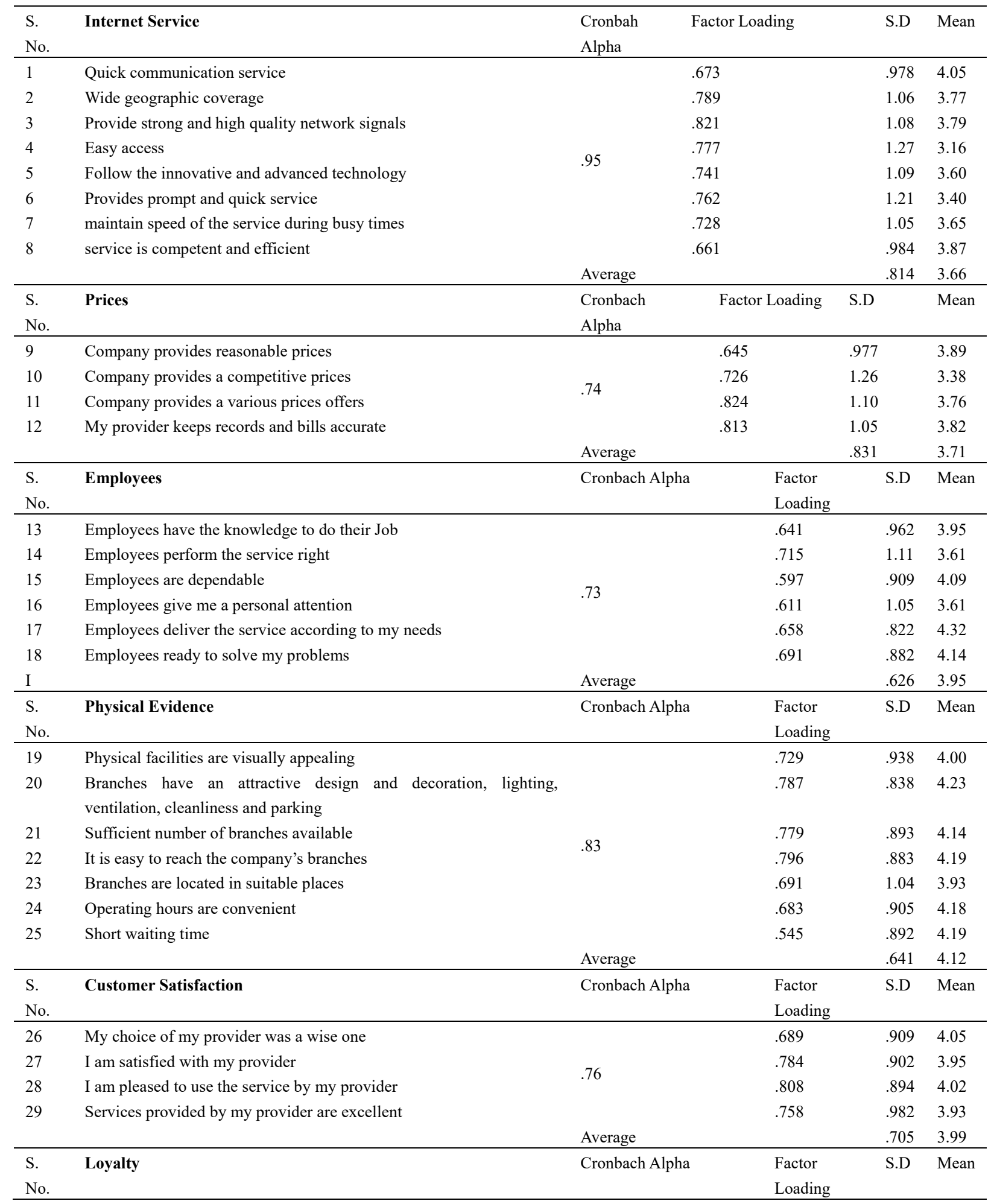




\begin{tabular}{|c|c|c|c|c|}
\hline 30 & I will deal with my provider more in future & .626 & .913 & 4.02 \\
\hline 31 & I would consider my provider as my first choice & .755 & 1.01 & 3.75 \\
\hline 32 & I will say favorable things about my provider & .805 & 1.15 & 3.43 \\
\hline 33 & I will recommend my provider to other people & .776 & 1.19 & 3.24 \\
\hline 34 & I will be loyal customer of this provider & .766 & 1.09 & 3.66 \\
\hline 35 & $\begin{array}{l}\text { I will not switch to competitors if my provider increase prices } \\
\text { somewhat }\end{array}$ & .568 & .972 & 3.99 \\
\hline
\end{tabular}

Table 2 refers to the analysis of the data gathered in reference to the sample responses to the paragraphs of the study. The results showed that the highest cronbach alpha appeared to be for the benefit of the internet service if I has the quality of an easy access with a rank of .95 followed by the physical evidence with a cronbach alpha of .83 referring to the paragraph " It is easy to reach the company's branches" as a good indicator. Generally speaking, it appeared that respondents had a positive attitude towards the variables of the study given that there mean appeared to be above 3 which is also considered to be as a good indicator.

\subsection{Assessment of Reliability and Validity}

In order to measure the value of reliability and validity of study, Cronbach Alpha and factor loading tests are used as shown in the table No. (2), to accept the measure Cronbach Alpha should be higher than .70. All the dimensions of study had a Cronbach Alpha value of .934, (Cronbach Alpha for internet service were .95, for prices were .74 , for Employees were .73 , physical evidence were .83 , forcustomer satisfaction were .76 and loyalty .79). More ever, Factor loading of all items of the study is more than .54 which is more than .50 as suggested by (Stewart, 1981).

\subsection{Hypothesis Testing}

\section{H (1): Internet Service Quality has a Significantly Positive Impact on Customer Satisfaction.}

Table 3. Regression analysis of internet service quality on customer satisfaction

\begin{tabular}{llllll}
\hline & $\mathrm{R}$ & $\mathrm{R}^{2}$ & Std. Error & $\mathrm{F}$ & Sig. \\
\hline Internet Service Quality & .67 & .46 & .521 & 175 & .000 \\
\hline
\end{tabular}

$\mathrm{P}<0.05$

Table 3 shows the results of the regression analysis reveals that $\left(\mathrm{R}^{2}\right)=.46$, which means that $46 \%$ of the overall of customer satisfaction was explained by internet service quality and remaining $54 \%$ can be attributed by other factors which are not studied, because they are beyond the scope of study. The result indicates that a positive correlation exists among service quality and customer satisfaction. More ever, the results show that the value of $\mathrm{F}=175$ and Sig. $=000$ which is less than the significant at the $95 \%$ of confidence level $\mathrm{P}<0.05$ of the study. Thus, Hypotheses (1) accepted.

H (2): Internet Service Quality Dimensions have a Significantly Positive Impact on Customer Satisfaction separately.

Table 4. Regression analysis of internet service quality dimensions on customer satisfaction

\begin{tabular}{lllllll}
\hline Variables & $\mathrm{B}$ & $\mathrm{R}^{2}$ & $\mathrm{~T}$ & Sig. & Tolerance & $\mathrm{VIF}$ \\
\hline Internet Service & .02 & .35 & .489 & .625 & .623 & 1.61 \\
Prices & .18 & .21 & 5.01 & .000 & .501 & 1.99 \\
Employees & .11 & .23 & 2.69 & .007 & .430 & 2.33 \\
Physical Evidence & .48 & .25 & 14.18 & .000 & .562 & 1.78 \\
\hline
\end{tabular}

$\mathrm{P}<0.05$

Before estimating the hypotheses (2), variance inflation factor (VIF) and tolerance were used to assess multicollinearity for each dimension of service quality as seen in table No. (4). According to Hair et el, (1995) 
suggest a cutoff value of $<10$ as an acceptable VIF. The collinearity test shows that the VIF occurs between 1.61 and 2.33 which indicate that multicollinearity among the dimensions is neglected.

In table (4), results for internet service quality dimensions impact on customer satisfaction have been analyzed separately. Regression analysis results as regard to internet service is $\left(\mathrm{R}^{2}\right)=.35$, prices is $\left(\mathrm{R}^{2}\right)=.21$, employees is $\left(\mathrm{R}^{2}\right)=.23$ and physical evidence is $\left(\mathrm{R}^{2}\right)=.25$. The results show that a positive correlation exists among internet service quality dimensions and customer satisfaction, which presents that the internet service attained the highest positive correlation, followed by physical evidence, employees and prices. Regression coefficients were used to identify the level of impact that internet service quality dimensions had on overall customer satisfaction. The findings indicated that coefficients of three out of four of the service quality dimensions were significant at the $95 \%$ of confidence level $(\mathrm{P}<0.05)$. The results of unstandardized coefficients indicated that the impact of internet service dimension is $(\beta=.02$, Sig. $=.625)$, prices $(\beta=.18$, Sig. $=.000)$, employees $(\beta=.11$, Sig. $=.007)$ and physical evidence $(\beta=.48$, Sig. $=.000)$. The above results of unstandardized coefficients indicated that internet service dimension has no impact on customer satisfaction and physical evidence gained the highest impact on customer satisfaction, followed by prices and employees.

\section{H (3): Internet Service Quality has a Significantly Positive Impact on Customer Loyalty.}

Table 5. Regression analysis of internet service quality on customer loyalty

\begin{tabular}{llllll}
\hline & $\mathrm{R}$ & $\mathrm{R}^{2}$ & Std. Error & $\mathrm{F}$ & Sig. \\
\hline Internet Service Quality & .68 & .45 & .555 & 177 & .000 \\
\hline
\end{tabular}

$\mathrm{P}<0.05$.

Table 5 shows the results of the regression analysis of internet service quality as independent variable and the customer loyalty as the dependent variable. Regression analysis reveals that $\left(\mathrm{R}^{2}\right)=.45$, which means that $45 \%$ of the overall of customer loyalty was explained by internet service quality and remaining $55 \%$ can be attributed by other factors which are not studied, because they are beyond the scope of study. The result indicates that a positive correlation exists among internet service quality and customer loyalty. More ever, the results show that the value of $\mathrm{F}=177$ and Sig. $=000$ which is less than the significant at the $95 \%$ of confidence level $\mathrm{P}<0.05$ of the study. Thus, Hypotheses (3) accepted.

\section{H (4): Service Quality Dimensions have a Significantly Positive Impact on Customer Loyalty separately.}

Table 6. Regression analysis of internet service quality dimensions on customer loyalty

\begin{tabular}{lllll}
\hline Variables & $\mathrm{B}$ & $\mathrm{R}^{2}$ & $\mathrm{~T}$ & Sig. \\
\hline Internet Service & .23 & .35 & 7.22 & .000 \\
Prices & .23 & .21 & 6.52 & .000 \\
Employees & .08 & .23 & 2.09 & .044 \\
Physical Evidence & .30 & .25 & 8.94 & .000 \\
\hline
\end{tabular}

$\mathrm{P}<0.05$.

In table 6 , results for service quality dimensions impacts on customer loyalty have been analyzed separately. Regression analysis results as regard to internet service is $\left(\mathrm{R}^{2}\right)=.35$, prices is $\left(\mathrm{R}^{2}\right)=.21$, employees is $\left(\mathrm{R}^{2}\right)=.23$ and physical evidence is $\left(\mathrm{R}^{2}\right)=.25$. The results show that a positive correlation exists among internet service quality dimensions and customer loyalty, which presents that the internet service attained the highest positive correlation, followed by physical evidence, employees and prices. Regression coefficients were used to identify the level of impact that internet service quality dimensions had on overall customer loyalty. The findings indicated that coefficients of four of the service quality dimensions were significant at the $95 \%$ of confidence level $(\mathrm{P}<0.05)$. The results of unstandardized coefficients indicated that the impact of internet service dimension is $(\beta=.23$, Sig. $=.000)$, prices $(\beta=.23$, Sig. $=.000)$, employees $(\beta=.08$, Sig. $=.044)$ and physical evidence $(\beta=.30$, Sig. $=.000)$. The above results of unstandardized coefficients indicated that physical evidence dimension gained the highest impact on customer loyalty, followed by internet service, prices and employees. Thus, Hypotheses (4) accepted.

\section{H (5): Service Quality and Customer Satisfaction have a Significantly Positive Impact on Customer}




\section{Loyalty.}

Table 7. Regression analysis of internet service quality and customer satisfaction on customer loyalty

\begin{tabular}{llllll}
\hline & $\mathrm{R}$ & $\mathrm{R}^{2}$ & Std. Error & $\mathrm{F}$ & Sig. \\
\hline Internet Service Quality & .72 & .52 & .523 & 181 & .000
\end{tabular}

$\mathrm{P}<0.05$.

Table 7 shows the results of the regression analysis of internet service quality as independent variable and the customer loyalty as the dependent variable. Regression analysis reveals that $\left(\mathrm{R}^{2}\right)=.52$, which means that $52 \%$ of the overall of customer loyalty was explained by internet service quality and remaining $48 \%$ can be attributed by other factors which are not studied. The result indicates that a positive correlation exists among service quality and customer loyalty. More ever, the results show that the value of $F=177$ and Sig. $=000$ which is less than the significant at the $95 \%$ of confidence level $\mathrm{P}<0.05$ of the study. Thus, Hypotheses (5) accepted.

H (6): Internet Service Quality Dimensions and Customer Satisfaction have a Significantly Positive Impact on Customer Loyalty separately.

Table 8. Regression analysis of internet service quality dimensions and customer satisfaction on customer loyalty

\begin{tabular}{llll}
\hline Variables & $\mathrm{B}$ & $\mathrm{T}$ & Sig. \\
\hline Internet Service & .23 & 7.487 & .000 \\
Prices & .17 & 5.054 & .000 \\
Employees & .04 & 1.179 & .239 \\
Physical Evidence & .14 & 3.991 & .000 \\
Customer Satisfaction & .34 & 10.410 & .000 \\
\hline
\end{tabular}

$\mathrm{P}<0.05$.

In table 8 , results for internet service quality dimensions impacts on customer loyalty have been analyzed separately. The results show that a positive correlation exists among service quality dimensions and customer loyalty, which presents that the internet service attained the highest positive correlation, followed by physical evidence, employees, customer satisfaction and prices. Regression coefficients were used to identify the level of impact that service quality dimensions had on overall customer loyalty. The findings indicated that coefficients of three out of four of the internet service quality dimensions and customer satisfaction were significant at the $95 \%$ of confidence level $(\mathrm{P}<0.05)$. The results of unstandardized coefficients indicated that the impact of internet service dimension is $(\beta=.23$, Sig. $=.000)$, prices $(\beta=.17$, Sig. $=.000)$, employees $(\beta=.04$, Sig. $=.239)$, physical evidence $(\beta=.14$, Sig. $=.000)$ and customer satisfaction $(\beta=.34$, Sig. $=.000)$. The above results of unstandardized coefficients indicated that customer satisfaction gained the highest impact on customer loyalty, followed by internet service, prices, and physical evidence. Employees has no impact on customer loyalty where $($ Sig. $=.239)$ is more than confidence level of the study $<0.05$.

\section{Discussion}

The current study aimed at understanding the influence of internet service quality and customer satisfaction on reaching the status of customer loyalty. The results of the study found an influence of the internet service quality on the customer satisfaction in a positive way, this means that the level of the service that is presented for customer can have an influence on their satisfaction in terms of attracting them to the service and satisfy them with the level of the service that they expect. On that idea, Ariff et al. (2013) argued that taking care of the level of the service can influence the satisfaction of customers. On the other hand, Khan and Fasih (2014) noted to the fact that the quality service can be very influential on the level of customer satisfaction specifically if that appeared through the e-service which can end up in influencing the overall performance of the organization. Also, Selvakumar (2015) accepted the influence of the service quality on the customer satisfaction on the bases of the fact that if a customer got the level of the service they expected their level of loyalty will raise and the image of the organization will be deeply influence. It was also reached through the results of the study that the level of the service quality along with its dimensions (prices, employees and physical evidence) can also influence the level of the level of customer satisfaction. The most influential variable of all appeared to be the physical evidence which can be seen as the most influential factor of all given factors. This matched what came along with Sakhaei, 
Afshari and Esmaili (2014) arguing that there is no relation between the service itself and the customer satisfaction; it is mostly the quality of the service and the physical evidence that counts to the customers and what basically raises their satisfaction towards a certain service.

On the idea of the internet service quality and its influence on customer loyalty, it was found out that there is a statistically significant influence of internet service quality and the idea of customer loyalty. It appeared that the more the service matched the expectations of the customers the more loyal they became to the organization. On the same idea Van Es, R.A.J (2012) argued that the level of the services and its quality influences the level of the customer satisfaction; at the same time the higher the customer satisfaction is the more the customers are welling to become loyal, in that sense we can find a correlation between the level of the service quality and the degree of customer loyalty through their satisfaction. Orel and Kara (2014) noted in their study to the influence of service quality on customer loyalty. They argued that the higher the service quality is the higher the probability of a better customer loyalty. Which also rhymed with the results of Osman and Sentosa (2016) who stated that the most influential factor on the level of customer loyalty is the degree of attention that the organization gives to the level of their service quality specifically when it come to the internet services (e-service).

Generally speaking, and through the analysis it was found out that internet service quality and customer satisfaction positively influences the level of customer loyalty to the organization. This appeared through the results and rhymed with the results of Siddiqi (2011) who also found an interrelation between the idea of customer satisfaction and the quality of the service in contact with the level of customer loyalty. Also Lenka, Suar and Mohapatra (2009) reached the same result arguing that the lean of the service may lead to customer satisfaction which in its turn can end up with having a higher level of customer loyalty. This can be seen as a logical result given that when an individual is satisfied with a certain service gradually the loyalty will lean towards that service that provides the best satisfaction.

\section{Conclusion and Recommendations}

The current study aimed at examining the mediating effect of customer satisfaction of the internet service quality on the level of the customer loyalty among a sample of Jordanian customers in the capital of Jordan Amman. The sample consisted of (860) customers as a convenient sample from different shopping malls and commercials complexes in Jordan- Amman. Through the use of the questionnaire it appeared from the statistical analysis that there is an influence of service quality on the customer loyalty through the mediating influence of the customer satisfaction. The results of the study indicated that a good and well-built service quality may lead to customer satisfaction which in its turn can lead to a better level of customer loyalty. Consumer loyalty includes highlights or attributes that can fulfill the desires or needs of a client, it is a post utilization encounter which contrasts apparent quality and expected quality, in this way a similar conduct between inputs previously and after utilization. Consumer loyalty is a conceptual idea where the real fulfillment differs from people and items relying upon various factors which incorporate administration quality and the individual desires. Low quality services, which does not achieve the clients' satisfaction, prompts customer disappointment, abnormal state of fulfillment is built up when the brand satisfies the necessities of clients much more than the contending brands. Shopper satisfaction is likewise observed as a key execution marker inside a business. There is confirming that organizing consumer loyalty is fundamental to enhance the business' gainfulness the two being emphatically related. Organizations in this manner now lift the part of clients to that of partners as an excellent business technique. Consumer loyalty in a business is basic. Unsatisfied customers rush to change from the brand which neglects to satisfy fundamental necessities. Moreover, it was noticed that a disappointed client may relate a terrible ordeal disintegrating potential support of the specialist organization.

Based on the aforementioned results and conclusion, the current study recommends the following:

- Enhance the level of service quality awareness is the best approach to customer satisfaction. Aware employees tend to pay more attention to the idea of service quality which can lead to a better customer loyalty.

Relying on the concept of CRM within the organization can be the best approach into reaching the best customer satisfaction and reaching loyalty at the end. Well-built CRM can help in preserving the current customers and attract potential customers.

- It was found out through the analysis that employees had no influence on the customer satisfaction and loyalty, from that point it is recommended that employees should be trained in a better and more scientific approach on how to deal with customers and satisfy them in order to gain their loyalty through the employees' attention to the details in the level of the service quality. 


\section{References}

Akbar, S., Som, A. P. M., Wadood, F., \& Alzaidiyeen, N. J. (2010). Revitalization of service quality to gain customer satisfaction and loyalty. International Journal of Business and Management, 5(6), 113-122. http://dx.doi.org/10.5539/ijbm.v5n6p113

Aktepe, A., Ersöz, S., \&Toklu, B. (2015). Customer satisfaction and loyalty analysis with classification algorithms and Structural Equation Modeling. Computers \& Industrial Engineering, 86, 95-106. http://dx.doi.org/10.1016/j.cie.2014.09.031

Alam, A., Malik, O. M., Hadi, N. U., \& Gaadar, K. (2016). barriers of online shopping in developing countries: case study of Saudi Arabia. European Academic Research, 3(12), 12957-12971.3-11.

Al-Rousan, M. R. and B. Mohamed (2010). "Customer loyalty and the impacts of service quality: The case of five star hotels in Jordan. International Journal of Human and Social Sciences, 5(13), 886-892.

Andaleeb, S.S., \& Conway, C. (2006). Customer satisfaction in the restaurant industry: An examination of the transaction-specific model. Journal of Services Marketing, 20(1), 3-11.

Anderson, E. W., \& Sullivan, M. W. (1993). The antecedents and consequences of customer satisfaction for firms. Marketing Science, 12(2), 125-143.

Ariff, M., Yun, L., Zakuan, N. and Ismail, K. (2013). The impacts of service quality and customer satisfaction on customer loyalty in internet banking. Procedia - Social and Behavioral Sciences, 81, 469-473.

Aydin, S., Ozer, G. K., \& Arasil, O. (2005). Customer loyalty and the effect of switching costs as a moderator variable: A case in the Turkish mobile phone market. Marketing Intelligence \& Planning, 23(1), 89-103. http://dx.doi.org/10.1108/02634500510577492

Bei, L. T., \& Chiao, Y. C. (2001). An integrated model for the effects of perceived product, perceived service quality, and perceived price fairness on consumer satisfaction and loyalty. Journal of Consumer Satisfaction, Dissatisfaction and Complaining Behavior, 14(3), 125-140.

Blodgett, J. G., Hill, D. J., \& Tax, S. S. (1997). The effects of distributive, procedural, and interactional justices on post complaint behavior. Journal of Retailing, 73(2), 185-210. http://dx.doi.org/10.1016/S0022-4359(97)90003-8

Cadotte, E., \& Turgeon, N. (1988). Dissatisfiers and satisfiers: suggestions from consumer complaints and compliments. Journal of Consumer Satisfaction, Dissatisfaction and Complaining Behaviour, 1, 74-79.

Chang, C. C. (2015). Exploring mobile application customer loyalty: The moderating effect of use contexts. Telecommunications Policy, 39(8), 678-690. http://dx.doi.org/10.1016/j.telpol.2015.07.008

Chang, Y., \& Chen, F. (2007). Relational benefits, switching barriers and loyalty: A study of airline customers in Taiwan. Journal of Air Transport Management, 104-109. http://dx.doi.org/10.1016/j.jairtraman.2006.10.001

Cronin Jr, J.J. and Taylor, S.A., (1992). Measuring service quality: A reexamination and extension. The journal of Marketing, 56(July), 55-68.

Gerpott, T. J., Rams, W., \& Schindler, A. (2001). Customer retention, loyalty and satisfaction in the German mobile cellular telecommunications market. Telecommunications Policy, 25(4), 249-269. http://dx.doi.org/10.1016/S0308-5961(00)00097-5

Gilbert, G. R., \&Veloutsou, C. (2007). A cross-industry comparison of customer satisfaction. Journal of Services Marketing, 20(5), 298-308.

Gotlieb, J. B. et al. (1994). Consumer satisfaction and perceived quality: complementary or divergent constructs? Journal of applied psychology, 79(6), 875.

Grönholdt, L., Martensen, A., \& Kristensen, K. (2000). The relationship between customer satisfaction and loyalty: cross-industry differences. Total Quality Management, 11(4/5/6), 509-514. http://dx.doi.org/10.1080/09544120050007823

Gupta, P., \& R. Srivastava (2011). Analysis of customer satisfaction in hotel service quality using analytic hierarchy process (AHP). International Journal of Industrial Engineering Research and Development (IJIERD), 2(1), 59-68.

Hair, J. F. Jr., Rolph, E. A., Ronald, L. T., \& William, C. B. (1995). Multivariate data analysis (4th ed.). Englewood Cliffs, NJ: Prentice Hall. 
Han, X., Kwortnik, Jr, R., \& Wang, C. (2008). Service Loyalty: An integrative model and examination across service contexts. Journal of Service Research, 11(1), 22-42.

Haq, A. (2012). Satisfaction towards customer loyalty in auto-mobile industry of Pakistan. International Journal of Management and Business Research, 2(4), 363-371.

Harr, K. K., \& Lily, K. (2008). Service dimensions of service quality impacting customer satisfaction of fine dining restaurants in Singapore. UNLV Theses, Dissertations, Professional Papers, and Capstones, 686.

Iglesias, M. P., \&Guillen, M. J. Y. (2004). Perceived quality and price: Their impact on the satisfaction of restaurant customers. International Journal of Contemporary Hospitality, 16(6), 373-379.

Ilieska, K., (2013). Customer satisfaction index-as a base for strategic marketing Management. TEM Journal, $4(2), 327-331$.

Irfan, M., Shamsudin, M. F., \& Hadi, N. U. (2016). How important is customer satisfaction? quantitative evidence from mobile telecommunication market. International Journal of Business and Management, 11(6), 57-69.

Khan, M. M., \& Fasih, M. (2014). Impact of service quality on customer satisfaction and customer loyalty: Evidence from banking sector. Pakistan Journal of Commerce \& Social Sciences, 8(2), 331 - 354.

Kim, M., Chang, Y., Park, M. C., \& Lee, J. (2015a). The effect of quality on the satisfaction and the loyalty of smartphone users. Telematics and Informatics, 32(4), 949-960. http://dx.doi.org/10.1016/j.tele.2015.05.003

Kim, M., Fan, S., Chang, Y., \& Park, J. (2016). Determinants of customer loyalty in the Korean smartphone market: Moderating effects of usage characteristics. Telematics and Informatics, 33(4), 936-949.

Kumar, V., Pozza, I. D., \& Ganesh, J. (2013).Revisiting the satisfaction-Loyalty relationship: Empirical generalization and directions for future research. Journal of Retailing, 89, 246-262. http://dx.doi.org/10.1016/j.jretai.2013.02.001

Lenka, U., Suar, D., \& Mohapatra, P. K. (2009). Service quality, customer satisfaction, and customer loyalty in Indian commercial banks. The Journal of Entrepreneurship, 18(1), 47-64.

Maxham, J. G., \& Netemeyer, R. G. (2002). Modelling customer perceptions of complaint handling over time: The effects of perceived justice on satisfaction and intent. Journal of Retailing, 78(4), 239-252. http://dx.doi.org/10.1016/S0022-4359(02)00100-8

Oliver, R. L. (1997). Satisfaction: A behavioral perspective on the consumer. New York, NY: McGraw-Hill, Inc.

Omachonu, V., Johnson, W. C., \& Onyeaso, G. (2008). An empirical test of the drivers of overall customer satisfaction: Evidence from multivariate qranger causality. Journal of Services Marketing, 22(6), 434-444. http://dx.doi.org/10.1108/08876040810901855

Omar, N. A., \& Omar. (2009). Parents' perceived service quality, satisfaction and trust of a childcare centre: implication on loyalty. International Review of Business Research Papers, 5(5), 299-314.

Orel, F. D., \& Kara, A. (2014). Supermarket self-checkout service quality, customer satisfaction, and loyalty: Empirical evidence from an emerging market. Journal of Retailing and Consumer Services, 21(2), 118-129.

Osman, Z., \& Sentosa, I. (2016). Influence of customer satisfaction on service quality and qustomer loyalty relationship in Malaysian commercial banking industry. International Journal of Economics, Finance and Management, 3(2), 115-120.

Parasuraman, A., Berry, L. L., \& Zeithaml, V. A. (1991). Understanding customer expectations of service. Sloan Management Review, 32(Spring), 39-48.

Parasuraman, A., Zeithaml, V. A., \& Berry, L. L. (1985). A conceptual model of service quality and its implications for future research. Journal of Marketing, 49(4), 41-50.

Parasuraman, A., Zeithaml, V. A., \& Berry, L. L. (1988). SERVQUAL: A multiple-item scale for measuring consumer perceptions of service quality. Journal of Retailing, 64(1), 12-37.

Raju, J. S., Srinivasan, V., \& Lal, R. (1990). The effects of brand loyalty on competitive price promotional strategies. Management Science, 36(3), 276-304.

Sakhaei, F., Afshari, A., \& Esmaili, E., (2014). The impact of service quality on customer satisfaction in internet banking. Journal of Mathematics and Computer Science, 9, 33-40.

Selvakumar, J. J. (2016). Impact of service quality on customer satisfaction in public sector and private sector 
banks. Purushartha: A Journal of Management Ethics and Spirituality, 8(1), 1-12.

Siddiqi, K. O. (2011). Interrelations between service quality attributes, customer satisfaction and customer loyalty in the retail banking sector in Bangladesh. International Journal of Business and Management, 6(3), 12-36.

Smith, A. K., \& Bolton, R. N. (2002). The effect of customers' emotional responses to service failure on their recovery effort evaluations and satisfaction judgments. Journal of the Academy of Marketing Science, 30(1), $5-23$.

Spreng, R. A., \& Mackoy, R. D. (1996). An empirical examination of a model of perceived service quality and satisfaction. Journal of Retailing, 72(2), 201-214.

Stewart, D. W. (1981). The Application and misapplication of factor analysis in marketing research, Journal of Marketing Research, 18, 51-62.

Supphellen, M., \& Nysveen, H. (2001). Drivers of intention to revisit the websites of well-known companies: The role of corporate brand loyalty. International Journal of Market Research, 43(3), 341-352.

Tax, S. S., \& Brown, S. W. (1998). Recovering and learning from service failure. Sloan Management Review, 40(1), 75-88.

Taylor, S. A. (1997). Assessing regression-based importance weights for quality perceptions and satisfaction judgments in the presence of higher order and/or interaction effects. Journal of Retailing, 73(1), 135-159.

Taylor, S. A., \& Baker, T. L. (1994). An assessment of the relationship between service quality and customer satisfaction in the formation of consumers' purchase intentions. Journal of retailing, 70(2), 163-178.

Teeter, C., \& Schointuch, B. (2000). Controlling internet service quality. Credit Union Executive Journal, 40(6), 6-11.

Van Es, R. A. J. (2012). The relationship between service quality and customer loyalty, and its influence on business model design-A study in the Dutch automotive industry. (Master's thesis, University of Twenty).

Vargo, S. L., Nagao, K., He, Y., \& Morgan, F. W. (2007). Satisfiers, Dissatisfiers, Criticals and Neutrals: A review of their relative effects on customer (dis)satisfaction. Academy of Marketing Science Review, 11(2), 509-533.

Wong, A., \& Zhou, L. (2006). Determinants and Outcomes of Relationship Quality: A Conceptual Model and Empirical Investigation. Journal of International Consumer Marketing, 18(3), 81-96. http://dx.doi.org/10.1300/J046v18n03_05

Zeithaml, V. A. et al. (1996). The behavioral consequences of service quality. Journal of Marketing, 60(April), 31-46.

Zeithaml, V. A., Bitner, M. J., \& Gremler, D. D. (2006). Services marketing: Integrating customer focus across the firm (4th ed., p.117). Singapore: McGraw-Hill.

\section{Copyrights}

Copyright for this article is retained by the author(s), with first publication rights granted to the journal.

This is an open-access article distributed under the terms and conditions of the Creative Commons Attribution license (http://creativecommons.org/licenses/by/4.0/). 